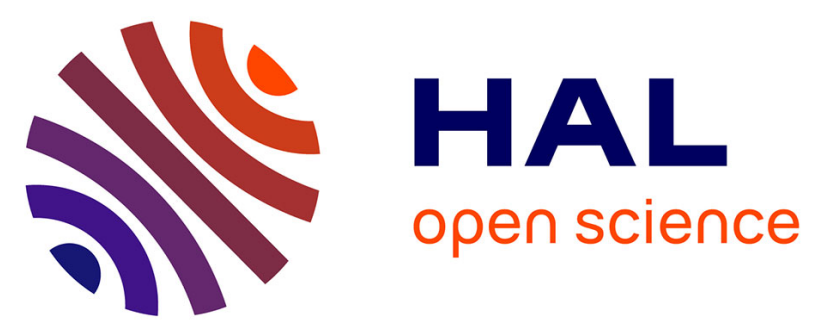

\title{
Assessing extracted organic matter quality from river sediments by elemental and molecular characterization: Application to the Tietê and Piracicaba Rivers (São
}

Carla Pereira de Morais, Amanda Maria Tadini, Lucas Raimundo Bento, Benjamin Oursel, Francisco Eduardo Gontijo Guimaraes, Ladislau Martin-Neto, Stéphane Mounier, Débora Marcondes Bastos Pereira Milori

\section{To cite this version:}

Carla Pereira de Morais, Amanda Maria Tadini, Lucas Raimundo Bento, Benjamin Oursel, Francisco Eduardo Gontijo Guimaraes, et al.. Assessing extracted organic matter quality from river sediments by elemental and molecular characterization: Application to the Tietê and Piracicaba Rivers (São. Applied Geochemistry, 2021, 131, pp.105049. 10.1016/j.apgeochem.2021.105049 . hal-03289516

\author{
HAL Id: hal-03289516 \\ https://hal.science/hal-03289516
}

Submitted on 17 Jul 2021

HAL is a multi-disciplinary open access archive for the deposit and dissemination of scientific research documents, whether they are published or not. The documents may come from teaching and research institutions in France or abroad, or from public or private research centers.
L'archive ouverte pluridisciplinaire HAL, est destinée au dépôt et à la diffusion de documents scientifiques de niveau recherche, publiés ou non, émanant des établissements d'enseignement et de recherche français ou étrangers, des laboratoires publics ou privés. 

molecular characterization: Application to the Tietê and Piracicaba Rivers (São

5 Carla Pereira de Morais ${ }^{1,2,3^{*}}$, Amanda Maria Tadini ${ }^{3}$, Lucas Raimundo Bento ${ }^{1,3}$,

6 Benjamin Oursel $^{2}$, Francisco Eduardo Gontijo Guimaraes ${ }^{4}$, Ladislau Martin-Neto ${ }^{3}$,

7 Stéphane Mounier ${ }^{2 *}$, Débora Marcondes Bastos Pereira Milori ${ }^{3 *}$

8

9 'São Carlos Institute of Chemistry, University of São Paulo, 13566-590, São Carlos, SP, 10 Brazil.

$11{ }^{2}$ University of Toulon, Aix Marseille University, CNRS/INSU, IRD, MIO UM 110,

12 Mediterranean Institute of Oceanography, CS 6058483041 - Toulon CEDEX 9, 13 France.

$14{ }^{3}$ Embrapa Instrumentation, 13560-970, São Carlos, SP, Brazil.

15 São Carlos Institute of Physics, University of São Paulo, 13566-590, São Carlos, SP, 16 Brazil.

17

$18 *$ Corresponding authors

19 Carla Pereira de Morais

20 E-mail: moraispcarla@gmail.com

21 Stéphane Mounier

22 E-mail: stephane.mounier@univ-tln.fr

23 Débora Marcondes Bastos Pereira Milori

24 E-mail: debora.milori@embrapa.br 


\section{Abstract}

28 Urban river pollution causes serious problems to the environment, human health, and

29 water scarcity. Developing tools to identify and assess the health of aquatic river

30 systems is essential for monitoring the quality of rivers and implementing actions. This

31 study assesses the elemental and molecular characteristics of organic matter (OM)

32 extracted from river sediments and associates them with river quality. To assess the

33 quality of sediment cores, the most reactive and available OM from two urban rivers

34 (Tietê and Piracicaba Rivers, São Paulo, Brazil) was isolated with alkaline and water

35 solutions. It was then characterized by elemental composition, ultraviolet-visible

36 spectroscopy, and fluorescence excitation-emission matrix with parallel factor analysis.

37 The average yield of alkaline extraction was $40.71 \% \pm 5.52 \%$ of OM present in the bulk

38 sediments. Extracted organic matter from sediments (EOMSed) from the Tietê River

39 presented the highest average concentrations of non-purgeable organic carbon (NPOC)

40 and total organic nitrogen (TON), and the lowest average NPOC/TON molar ratios and

41 specific UV absorbance at $254 \mathrm{~nm}\left(\mathrm{SUVA}_{254}\right)$. Considering the high degree of

42 eutrophication in the Tietê River, these results suggest a greater input of simple OM

43 with nitrogenous structures. The humic-like component in EOMSed was the most

44 abundant in both rivers. The aromaticity of EOMSed from the Piracicaba River was

45 evidenced by the greater contribution of complex structures in the form of aromatic and

46 polyaromatic moieties and higher $\mathrm{SUVA}_{254}$. EOMSed from the Tietê River also featured

47 enhanced biological activity due to the greater contribution of microbial-derived

48 products and the presence of small molecules and nitrogenous structures. As this

49 combination of elemental and spectroscopic techniques successfully identified the 
50 characteristics of extracted $\mathrm{OM}$, it can be used as a tool to assess the global river

51 quality.

52 Keywords: River sediments, Extracted organic matter, Fluorescence, Parallel factor 53 analysis.

54

55

56

57

58

59 (Murdoch and MacKnight, 1991; Schorer and Eisele, 1997). The sediments are

60 biogeochemically active due to the presence of many microbes and the continuous input

61 of organic and inorganic substances (He et al., 2019; Kumwimba et al., 2017).

62

63 (allochthonous) or from the aquatic ecosystem itself (autochthonous) (Brailsford et al.,

64 2019; Kindler et al., 2011). Moreover, rivers are responsible for transferring carbon (C)

65 between the terrestrial biosphere and oceans, where this element is transformed and

66 stored (Cole et al., 2007). In sediments, bacteria consume or decompose organic

67 particles, thus reducing the mass of OM (Bloesch, 2009). The organic material resistant

68 to microbial action and any remaining products are deposited on the bottom of rivers,

69 along with terrestrial sediments (Burdige, 2007; Henrichs, 1992). OM is then

70 remineralized, altered, or preserved during early diagenesis, which records input history

71 (Engel and Macko, 2013).

72

73 anthropogenic actions that cause extensive changes in the aquatic environment

74 (Bloesch, 2009). The excessive load of nutrients leads to the eutrophication of rivers, 
75 which is a process of increasing the OM load in an aquatic ecosystem (Nixon, 1995). In

76 areas with a high population density, the main sources of nutrients are domestic sewage

77 discharge, industrial effluent, and water drained from agricultural areas (Kubo and

78 Kanda, 2020; Smith et al., 2014). Sediments with high OM content promote oxygen

79 consumption through decomposition, which can harm aquatic animals and plants

80 (Duarte, 1995).

81 Barra Bonita Reservoir in São Paulo State, Brazil, is formed by the damming of 82 the Tietê and Piracicaba Rivers, and it is the first of six reservoirs of the Middle Tietê

83 River Basin (Rodrigues et al., 2020). The Tietê and Piracicaba basins have different

84 water resource management strategies, with different types of land use and occupation

85 (Cruz et al., 2017). Both rivers receive a high degree of organic compounds, although

86 the Tietê River is more eutrophic than the Piracicaba River, because it receives a large

87 load of industrial and domestic waste (dos Santos et al., 2006; Morais et al., 2021;

88 Rodrigues et al., 2020). The Middle Tietê River had a biochemical oxygen demand 89 (BOD) of 33,636 t day ${ }^{-1}$ in 2017 (CETESB, 2018). Before reaching the reservoir, the 90 Tietê River passes through the metropolitan area of São Paulo (Upper Tietê River), 91 which has a high population density and presented a BOD of $612,069 \mathrm{t}^{-1 a y}{ }^{-1}$. This 92 represents $57 \%$ of BOD of the Tietê River. By comparison, the Piracicaba Basin had a 93 BOD of 94,818 $\mathrm{t} \mathrm{day}^{-1}$ (CETESB, 2018). According to the State of São Paulo 94 Environmental Company (CETESB), the courses of both aquatic bodies are situated in 95 industrial areas marked by a high demographic density and intense land use (CETESB, 96 2018). However, regarding the course of the Middle Tietê River, its non-compliance 97 with water-quality standards stands at around $100 \%$ due to the untreated sewage 98 discharge in this stretch of the Tietê River (CETESB, 2018). 
In the current scenario of scarce freshwater resources in terms of both the quality

100 and quantity available for use, it is urgent to restore water bodies. One way to do so is to

101 focus on assessing OM quality in sediments. Furthermore, finding the tools to identify

102 and assess the health of aquatic river systems is essential for the implementation of

103 actions. Molar $\mathrm{C}$ to nitrogen $(\mathrm{N})$ ratios can be useful to identify the origin of $\mathrm{OM}$

104 (Burone et al., 2003; Meyers, 1994), whereas determining the optical properties of OM

105 present in sediments is also a rapid and efficient way to assess the quality of water

106 resources and obtain information about anthropogenic activities (Du et al., 2021). OM is

107 a small fraction of the sediment compared to the inorganic fraction. The extraction is

108 carried out to isolate part of the OM and obtain information about its origin and quality.

109 For this purpose, water or basic extractants have shown their potential for determining

110 the quality and origin of OM in sediments (Brym et al., 2014; Funkey et al., 2019). The

111 neutral aqueous medium allows for the extraction of polar substances of small

112 molecular weight, which are free from the mineral fraction in the sediments. Water

113 alkaline extraction favors the extraction of more polar or reactive substances, even

114 allowing for the extraction of substances linked to minerals (Olk et al., 2019). After the

115 extraction with neutral and basic water, there remains only an insoluble organic fraction

116 that is strongly linked to minerals. This can be considered a stable or less reactive OM,

117 which will hardly influence the chemical processes in the sediment (Guigue et al., 2014;

118 Muller et al., 2014; Olk et al., 2019).

119 To assess the sediment quality, the most available and reactive OM was isolated

120 with neutral and alkaline water solutions. It was then fully characterized by elemental

121 composition, ultraviolet-visible spectroscopy (UV-Vis), and fluorescence excitation-

122 emission matrix (EEM) processed with parallel factor analysis (PARAFAC). This study

123 aimed to evaluate the elemental and molecular features of the extractable OM of 
124 sediments taken from the Piracicaba and Tietê Rivers and associate this information

125 with the global river quality.

126

127 2. Materials and methods

128 2.1. Study area description and sediment sampling

129 The study area covers the Tietê and Piracicaba Rivers upstream from the Barra

130 Bonita Reservoir. The Barra Bonita Reservoir, located between the cities of Barra

131 Bonita and Igaraçu do Tietê, was created from the flooding and damming of these rivers

132 (Bernardo et al., 2016). The Tietê and Piracicaba Rivers pass through large urban

133 centers until their confluence. Both rivers receive a large load of organic and inorganic

134 pollutants, which are delivered to the reservoir, although a greater load of pollutants is

135 dumped into the Tietê River (Smith et al., 2014). The study area was chosen due to the

136 different uses and occupations of the soil in this region, characterized by pollution

137 issues and multiple uses of water. Furthermore, this region has suffered from many

138 anthropic actions, mainly due to deforestation and flooding for the construction of six

139 successive reservoirs, with the Barra Bonita Reservoir being the first (Rodrigues et al., 140 2020).

141 The sediment cores were collected at seven points: three on the Piracicaba River

142 (stations 1, 2, and 3), one at the confluence region (station 4), and three on the Tietê

143 River (stations 5, 6, and 7) (Figure 1) (Morais et al., 2021). The collection points were

144 georeferenced using a GPS Trimble Navigation unit as shown in the supplementary

145 material (Table S1); the sampling took place on July 25, 2017 (austral winter). The

146 sediment samples were collected using core sampling, which allowed us to maintain the

147 original deposition of sedimentary layers. The horizontal slicing was performed at the

148 same time as the sample collection, in different sizes (Table S2) under normal 
149 atmosphere along the sediment cores without removing the interstitial water, thus

150 totaling 69 sample layers. The sediment samples were immediately packed into

151 polypropylene flasks and kept in a thermal box during transport to the laboratory to

152 avoid the oxidation effect.

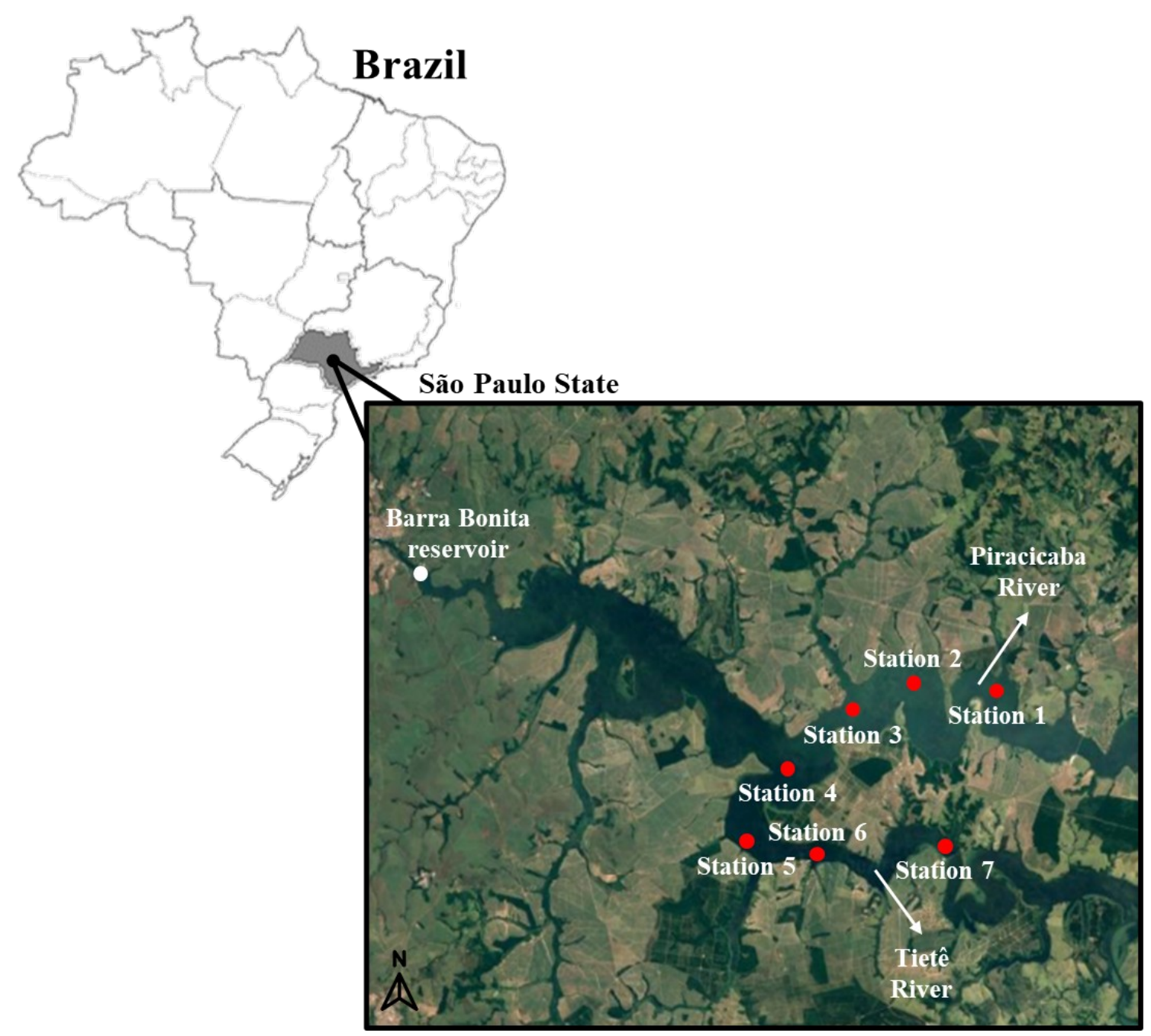

Figure 1: Location of the Barra Bonita Reservoir (white dot) and sediment sample

155 collection stations (red dots).

\subsection{Elemental analysis}

The sediment samples were frozen, freeze-dried (L101, Liotop), crushed using an automatic mortar grinder (RM 200, Retsch), and sieved through a 100-mesh sieve. 
161 combustion method. For this purpose, $20 \mathrm{mg}$ of the homogenized samples were 162 accurately weighed directly in the tin capsules. The standard used in the analysis was 163 aspartic acid, and the method was validated using the soil certified reference material 164 (ThermoFisher Soil Reference Material NC PN338 40025). All measurements were 165 performed in an elemental analyzer (Flash 2000, ThermoFisher Scientific).

166

167 2.3. Extractable organic matter from sediment samples

168 2.3.1. Extraction

169 The alkaline extraction was performed with $\mathrm{NaOH}$ to isolate $\mathrm{OM}$ in the sediment 170 samples taken from the Piracicaba and Tietê Rivers. The sediment extracts were 171 denominated EOMSed (extracted organic matter from sediments). Approximately $1.0 \mathrm{~g}$ 172 of each sample was placed in polypropylene flasks with $45.0 \mathrm{~mL}$ of $0.1 \mathrm{~mol} \mathrm{~L}^{-1} \mathrm{NaOH}$ 173 (ThermoFisher Scientific) and shaken for $24 \mathrm{~h}$ in an overhead shaker (Rex 20, 174 Heidolph) at $10 \mathrm{rpm}$. The samples were then centrifuged (Sigma 3-18K, Grosseron) at $17510,000 \mathrm{rpm}$ for $10 \mathrm{~min}$ and filtered over $0.45 \mu \mathrm{m}$ syringe filters (Minisart NML, 176 Sartorius). Furthermore, another extraction method was conducted in the same way as 177 previously described with $45.0 \mathrm{~mL}$ ultrapure water (Ultrapure Water Cell, Starna Ltd) in 178 which the extracts from sediments were denominated WEOMSed (water-extracted 179 organic matter from sediments).

181 2.3.2. Non-purgeable organic carbon and total organic nitrogen determination Non-purgeable organic carbon (NPOC) and total organic nitrogen (TON) from 183 EOMSed were quantified after dilution with ultrapure water to fit the standard NPOC 184 calibration curve (maximum $30 \mathrm{mg} \mathrm{L}^{-1}$ of C). The extracts were acidified and measured 185 using an elemental analyzer (TOC-V Shimadzu). The NPOC/TON molar ratios were 
186 calculated. The extraction yield was obtained by dividing the quantity of organic carbon

187 (OC) in the extracted solution in mg (NPOC multiplied by the extraction volume) by the

188 carbon content in the corresponding sediment in mg (TC multiplied by extracted mass

189 sample).

190

191 2.3.3. UV-Vis spectroscopy

192

Absorbance measurements were performed for all EOMSed and WEOMSed

193

194

195

196 EOMSed and WEOMSed, respectively. From the absorbance measurements, it was

197 possible to define the dilution factor for fluorescence. Thus, all samples had the

198 absorbance adjusted to 0.1 at $254 \mathrm{~nm}$, thus allowing their comparisons by avoiding the

199 inner filter effect for the fluorescence analysis (Kothawala et al., 2013). Specific UV

200 absorbance at $254 \mathrm{~nm}\left(\mathrm{SUVA}_{254}\right)$ was calculated by dividing the UV absorbance

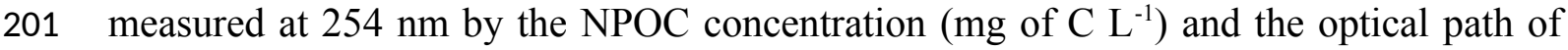

202 the cuvette $(0.01 \mathrm{~m})$ (Weishaar et al., 2003).

203

204

205

206

207

208

209

210

\subsubsection{Fluorescence spectroscopy}

\subsubsection{Sample preparation and analysis}

For the study of EEM, $1.0 \mathrm{~mL}$ of each sample diluted to absorbance at $254 \mathrm{~nm}$ equal $0.1\left(1 \mathrm{~cm}\right.$ path length) was placed in quartz cells along with $1.0 \mathrm{~mL}$ of $0.3 \mathrm{~mol} \mathrm{~L}^{-1}$ HEPES (Acros Organics) for pH regulation at 7 and $1.5 \mathrm{~mL}$ of $0.1 \mathrm{~mol} \mathrm{~L}^{-1} \mathrm{NaClO}_{4}$ (Sigma-Aldrich) with a purity of $99.99 \%$ to fix ionic strength. The samples were analyzed immediately after preparation. 
All measured spectra were obtained with a fluorescence spectrofluorometer

212 (F4500, Hitachi). The EEM spectra were acquired with an excitation range from 200 to

$213500 \mathrm{~nm}$ and an emission range from 250 to $700 \mathrm{~nm}$ at a scan speed of $2400 \mathrm{~nm} \mathrm{~min}{ }^{-1}$.

214 The steps and slits of emission and excitation were fixed at $5 \mathrm{~nm}$, and the detector

215 voltage was $700 \mathrm{~V}$. Both emission and excitation detectors were corrected to prevent

216 wavelength sensitivity. The Raman spectrum of ultrapure water (Ultrapure Water Cell,

217 Starna Ltd) was measured on a daily basis with excitation at $350 \mathrm{~nm}$, scan speed at

$218240 \mathrm{~nm} \mathrm{~min}-1$, emission from 360 to $420 \mathrm{~nm}$, and excitation and emission slit fixed at

$2195 \mathrm{~nm}$ and $700 \mathrm{~V}$ to normalize the EEM intensity with the Raman scattering peak

220 (Lawaetz and Stedmon, 2009).

\subsubsection{Fluorescence data processing}

PARAFAC was conducted on the EEM dataset using PROGMEEF software

224 (https://woms18.univ-tln.fr/progmeef/) in Matlab language. All the EEMs were cleaned

225 from the diffusion signals using Rayleigh scattering by cutting the diffusion band in 15

$226 \mathrm{~nm}$ and using first- and second-order Raman scattering by applying the Zeep method

227 (Mounier et al., 2011; Zepp et al., 2004). The number of evaluated components varied

228 from 2 to 5 in a spectral range from 240 to $500 \mathrm{~nm}$ in excitation and from 250 to 700

$229 \mathrm{~nm}$ in emission. The number of components was defined using the core consistency

230 diagnostic (CORCONDIA). The optimal rank was the model giving the higher number

231 of components with a CORCONDIA over 60\% (Mounier et al., 2011). The excitation

232 and emission of components obtained by PARAFAC were compared to the OpenFluor

233 database (Murphy et al., 2014).

\subsection{Statistical analysis}


237 TC in bulk sediments from the Tietê and Piracicaba Rivers and NPOC, TON, 238 NPOC/TON molar ratios, and SUVA values obtained for EOMSed from the Tietê and 239 Piracicaba Rivers. The correlation coefficient between the NPOC/TON molar ratios and 240 the $\mathrm{SUVA}_{254}$ values was calculated.

\section{Results and discussion}

\subsection{Total carbon characteristics in bulk sediments}

The distributions of TC content in the bulk sediment cores in the Piracicaba and

245 Tietê Rivers were different (Figure 2). In the collection stations of the Piracicaba River

246 (stations 1,2, and 3), the highest TC value was found in the upper layer of the sediment 247 cores, and a decrease in TC content was observed at the lower layers of the vertical 248 distribution. In station 1, TC varied from $1.96 \%$ to $2.60 \%$ with a coefficient of variation $249(\mathrm{CV})$ of 0.10 , and the lowest value at a depth of $41 \mathrm{~cm}$. In station 2, TC varied from $2502.12 \%$ to $3.32 \%(\mathrm{CV}=0.15)$, and despite the decrease in TC when entering the 251 sediment, it was possible to observe an increase in TC content between the depths of 30 $252 \mathrm{~cm}$ and $32 \mathrm{~cm}$. In station 3, TC varied from $2.24 \%$ to $4.94 \%(\mathrm{CV}=0.30)$, although it 253 decreased exponentially from the surface to a depth of $27.5 \mathrm{~cm}$, and from that depth, it 254 remained almost constant. In the confluence region, TC varied from $2.44 \%$ to $5.76 \%$ $255(\mathrm{CV}=0.27)$, although the highest TC content is found in the surface layer, as in the 256 collection stations of the Piracicaba River. Its behavior is more similar to the collection 257 stations located on the Tietê River, which present a random TC distribution in the 258 deeper layers of the sediment cores. TC variation in the Tietê River ranged from 3.09\% 259 to $6.59 \%(\mathrm{CV}=0.19), 1.44 \%$ to $3.66 \%(\mathrm{CV}=0.26)$, and $3.25 \%$ to $5.77 \%(\mathrm{CV}=0.19)$ 260 at stations 5,6 , and 7 , respectively. 

inorganic carbon (IC) in sediments (Veres, 2002). The random distribution of TC in the

263 Tietê River may be associated with an irregular input of OM and IC. A unpaired t-test

264 with a 95\% confidence level showed that there were significant differences between the 265 average $\mathrm{TC}$ of the rivers. The average TC content in the Tietê River $(3.96 \pm 1.11)$ is 266 higher than in the Piracicaba River $(2.57 \pm 0.58)$. The highest TC content for the Tietê 267 River suggests that this river is more eutrophic than the Piracicaba River, since the 268 accumulation of nutrients, mainly $\mathrm{P}$ and $\mathrm{N}$, in the aquatic bodies increases the synthesis 269 of OM (Castillo, 2020). This hypothesis is corroborated by a study that we previously 270 published on the quantification of total phosphorus (TP) in the same sediment samples 271 studied here (Morais et al., 2021). As TP is a chemical variable used to assess the 272 nutrient load and the extent of eutrophication in water bodies, the higher average TP 273 content in the Tietê River $\left(4316.16 \pm 1062 \mathrm{mg} \mathrm{kg}^{-1} \mathrm{P}\right)$ than in the Piracicaba River $274\left(1800.17 \pm 696.82 \mathrm{mg} \mathrm{kg}^{-1} \mathrm{P}\right)$ indicates that this river has a higher degree of 275 eutrophication (Morais et al., 2021). 
TC (\%)
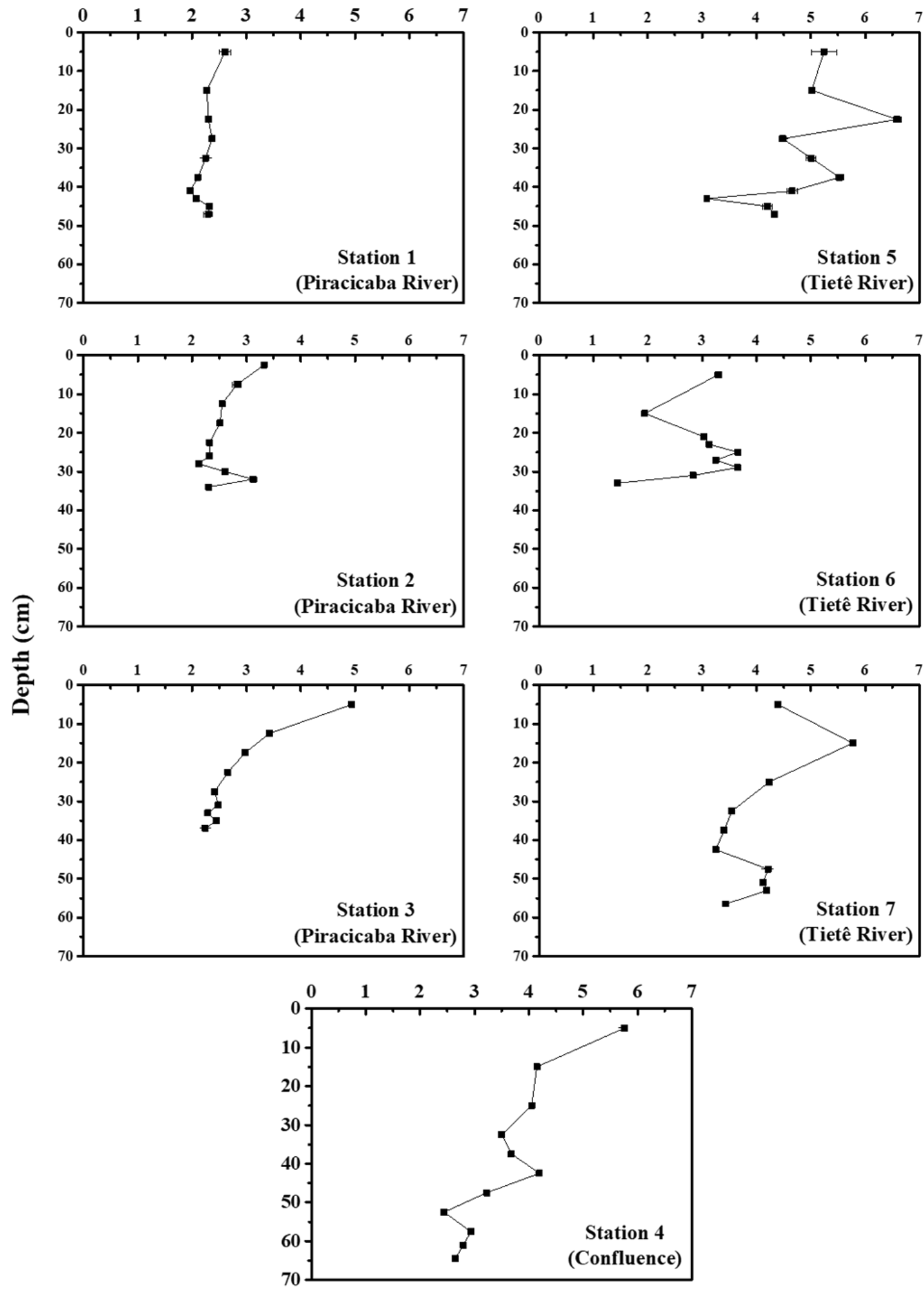

277 Figure 2. Total carbon distribution inside the sediment cores at the collection stations. 


\subsection{Characteristics of extracted organic matter from sediments}

Table 1 shows the average concentration of NPOC and TON, alkaline extraction yield, NPOC/TON molar ratio, and $\mathrm{SUVA}_{254}$ of EOMSed at the different stations. These values for each sample are shown in the supplementary material (Table S3). The extraction method with alkaline solution extracted an average of $40.71 \% \pm 5.52 \%$ of OM present in the bulk sediments. The yield of OM extraction depends on the property of the extractant and is generally low. Among the different extractants used for OM extraction, $\mathrm{NaOH}$ seems to be the most effective (Kurek et al., 2020; Sire et al., 2009).

Table 1. Average concentration of non-purgeable organic carbon (NPOC) and total organic nitrogen (TON), alkaline extraction yield, NPOC/TON molar ratio, and specific UV absorbance at $254 \mathrm{~nm}\left(\mathrm{SUVA}_{254}\right)$ of the extracted organic matter from sediments at the collection stations.

\begin{tabular}{|c|c|c|c|c|c|}
\hline \multirow[b]{2}{*}{ Station } & \multicolumn{5}{|c|}{ Extraction } \\
\hline & 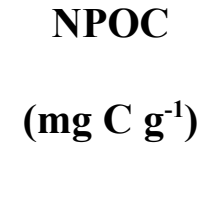 & $\begin{array}{c}\text { TON } \\
\left(\mathrm{mg} \mathrm{N} \mathrm{g}^{-1}\right)\end{array}$ & $\begin{array}{l}\text { yield } \\
(\%)\end{array}$ & $\begin{array}{c}\text { NPOC/TON } \\
\text { ratio }\end{array}$ & $\begin{array}{c}\mathrm{SUVA}_{254} \\
\left(\mathrm{~L} \mathrm{mg}^{-1} \mathrm{~m}^{-1}\right)\end{array}$ \\
\hline 1 & $9.02 \pm 0.84$ & $1.14 \pm 0.11$ & $40.63 \pm 5.17$ & $6.80 \pm 0.20$ & $6.36 \pm 0.53$ \\
\hline 2 & $10.65 \pm 1.71$ & $1.25 \pm 0.24$ & $41.03 \pm 3.58$ & $7.37 \pm 1.00$ & $5.99 \pm 0.69$ \\
\hline 3 & $12.59 \pm 1.98$ & $1.75 \pm 0.38$ & $45.23 \pm 6.56$ & $6.22 \pm 0.49$ & $6.11 \pm 1.08$ \\
\hline 4 & $13.54 \pm 4.82$ & $2.40 \pm 0.76$ & $37.17 \pm 5.61$ & $4.78 \pm 0.30$ & $4.54 \pm 0.73$ \\
\hline 5 & $19.60 \pm 5.74$ & $3.01 \pm 0.74$ & $40.11 \pm 5.17$ & $5.53 \pm 0.50$ & $3.92 \pm 0.61$ \\
\hline 6 & $11.90 \pm 3.54$ & $2.00 \pm 0.52$ & $40.50 \pm 3.96$ & $5.05 \pm 0.37$ & $3.70 \pm 0.51$ \\
\hline 7 & $16.24 \pm 2.31$ & $2.51 \pm 0.45$ & $41.05 \pm 6.36$ & $5.59 \pm 0.32$ & $4.44 \pm 0.83$ \\
\hline
\end{tabular}


A unpaired t-test at the $95 \%$ confidence level demonstrated that there were 294 significant differences in the NPOC and TON averages of EOMSed in the Tietê and 295 Piracicaba Rivers. The average concentration of NPOC and TON of EOMSed in the 296 Tietê River $\left(16.05 \pm 5.10 \mathrm{mg} \mathrm{C} \mathrm{g}^{-1}\right.$ and $2.52 \pm 0.70 \mathrm{mg} \mathrm{N} \mathrm{g}^{-1}$, respectively) was higher 297 than that in the Piracicaba River $\left(10.69 \pm 2.11 \mathrm{mg} \mathrm{C} \mathrm{g}^{-1}\right.$ and $1.37 \pm 0.37 \mathrm{mg} \mathrm{N} \mathrm{g}^{-1}$, 298 respectively). The highest NPOC concentrations of EOMSed in the Tietê River may be 299 due to the fact that the river passes through the metropolitan area of São Paulo, where it 300 receives a large load of domestic sewage and industrial effluents, resulting in a larger 301 biological oxygen demand than the Piracicaba River (CETESB, 2018). Furthermore, 302 taking into account the history of the Tietê River, its high degree of contamination 303 (Rocha et al., 2011, 2010) and eutrophication (Morais et al., 2021), the higher TON 304 concentration of EOMSed in the Tietê River when compared to the Piracicaba River 305 may be due to the sewage discharge containing labile and fresh OM. The average NPOC/TON molar ratios of EOMSed in the Tietê and Piracicaba 307 Rivers were statistically different ( $95 \%$ confidence level, unpaired t-test) and were 308 higher for the Piracicaba River $(6.80 \pm 0.79)$ compared to the Tietê River $(5.39 \pm 0.46)$. 309 Considering the historical course of the Tietê River and its high degree of 310 eutrophication (Morais et al., 2021), the lower ratios found in the river may suggest a 311 larger input of simple OM with nitrogenous structures, which may indicate effluent 312 input. In the confluence region, the NPOC/TON molar ratio of EOMSed was the lowest: $3134.78 \pm 0.30$. The lower value of the NPOC/TON molar ratio shows an increase in OM 314 deposition with nitrogenous structures, suggesting that the confluence region is 315 predominantly influenced by the Tietê River, which showed the highest nitrogen 
concentrations (range of 2.00-3.01 $\mathrm{mg} \mathrm{N} \mathrm{g}^{-1}$ ). Despite the difference in the NPOC/TON molar ratios of EOMSed between the Tietê and Piracicaba Rivers, the studied EOMSed 318 showed a NPOC/TON molar ratio that varied from 4.1 to 9.2 (Figure 3). The 319 NPOC/TON molar ratios between 4 and 10 categorize the sources of $\mathrm{C}$ and $\mathrm{N}$ of algae 320 and aquatic plants (Kaushal and Binford, 1999; Meyers, 1994). $\mathrm{SUVA}_{254}$ is associated with the aromaticity of $\mathrm{OM}$ due to the carbon double 322 bond $(\mathrm{C}=\mathrm{C})$ of aromatic moieties or polycondensated aromatic rings that absorb light at 323 $254 \mathrm{~nm}$ (Edzwald and Tobiason, 2011). Therefore, high SUVA 254 values indicate an

324 OM formed by more structures that absorb light at $254 \mathrm{~nm}$ per unit concentration of OC 325 (Edzwald and Tobiason, 2011). The average SUVA 254 values of EOMSed in the 326 Piracicaba and Tietê Rivers were statistically different (95\% confidence level, unpaired 327 t-test) and were higher for the Piracicaba River $(6.16 \pm 0.78)$ than the Tietê River $(4.02$ $328 \pm 0.71)$. The confluence region showed SUVA $_{254}$ values of EOMSed closer to the Tietê 329 River (average SUVA $_{254}$ values was $4.54 \pm 0.71 \mathrm{~L} \mathrm{mg}^{-1} \mathrm{~m}^{-1}$ ). SUVA 254 showed 330 differences in the composition of EOMSed between the two rivers, with the higher 331 average $\mathrm{SUVA}_{254}$ values for the Piracicaba River indicating that EOMSed has a 332 relatively high aromatic content compared to the Tietê River. The NPOC/TON molar ratios of EOMSed were correlated with the $\mathrm{SUVA}_{254}$ 334 values (Figure 3). Regression analysis found a positive relationship between the 335 NPOC/TON molar ratio and $\operatorname{SUVA}_{254}(r=0.67 ; p<0.001)$. By analogy to soil OM, 336 these results could be associated with the functional complexity of EOMSed (Dungait et 337 al., 2012; Lehmann et al., 2020). During the degradation of OM, the more polar 338 structures are more accessible to microorganisms and are thus consumed faster, 339 resulting in an accumulation of $\mathrm{OM}$ that is thermodynamically unfavorable to 340 microorganisms (hydrophobic and aromatic moieties). The relatively lower presence of 
$341 \mathrm{~N}$ suggests that these structures have already been totally or partly assimilated, resulting 342 in the selective preservation and accumulation of more chemically stable structures, 343 which led to greater aromaticity in the Piracicaba River. Conversely, the lower SUVA 254 344 and NPOC/TON molar ratio in the Tietê River suggest the addition of fresh OM. This 345 evidence is supported by the high BOD value of the Tietê River.

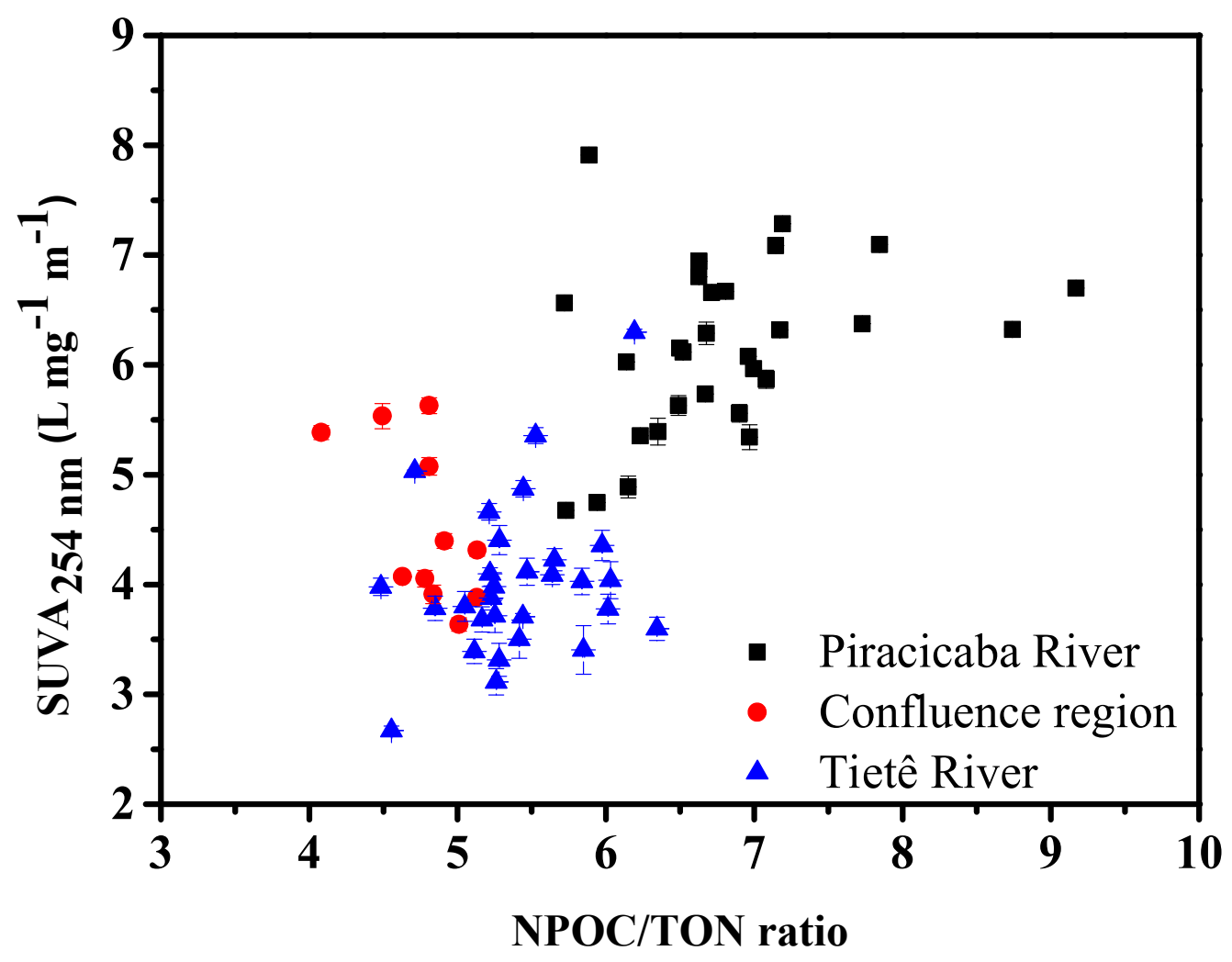

347 Figure 3. Relationship between specific UV absorbance at $254 \mathrm{~nm}\left(\mathrm{SUVA}_{254}\right)$ and non348 purgeable organic carbon (NPOC) and total organic nitrogen (TON) molar ratios of 349 extracted organic matter from sediments.

3.3. Fluorescence excitation-emission matrix spectra of organic matter extracted from sediments with alkaline and neutral water solutions

WEOMSed diluted to the same optical density resulted in three fluorescent components (Figure 4) with a CORCONDIA of $89.98 \%$. The spectral characteristics of the three 
356

357

358

359 360 database.

361

components were compared to the OpenFluor database (Murphy et al., 2014), and similarity was measured with the PARAFAC models from different aquatic environments using the EEM similarity score of 0.95 . Components 1,2 , and 3 respectively corresponded to PARAFAC models 35, 5, and 25 from the OpenFluor

Component 1 (C1) had two excitation maxima: one in $260 \mathrm{~nm}$ stimulated by UV excitation (peak A), and the other in $310 \mathrm{~nm}$ stimulated by visible excitation, with an emission maximum in the visible range at $465 \mathrm{~nm}$ for both excitation peaks (Coble, 1996). Component 2 (C2) was comprised of two excitation maxima at $285 \mathrm{~nm}$ and 465 $\mathrm{nm}$, and an emission maximum at $520 \mathrm{~nm}$ (Osburn et al., 2011; Walker et al., 2013). The fluorescence emission is useful to access the structural arrangement of OM due to the fluorophore emission in short (blue-shift) or long wavelength (red-shift). C1 and C2 had similar characteristics to soil fulvic and humic acids, respectively. $\mathrm{C} 1$ resembles fulvic acids due to the shorter wavelength emission, and the blue-shifted component is attributed to the lower molecular weight and a structural arrangement comprised of more alkyl moieties (Borisover et al., 2009; Kowalczuk et al., 2009; Osburn et al., 2016, 2011; Shutova et al., 2014; Yamashita et al., 2010b, 2010a). C2 resembles humic acids from the soil due to the red-shifted component, which is attributed to a more complex structural arrangement mainly composed of aromatic moieties (Soares da Silva et al., 2020). Furthermore, the shift in the wavelength concerns the aggregation of humic structures in solution; a red-shifted humic structure can show a molecular arrangement with higher molecular aggregation, while a shorter wavelength suggests smaller molecules (Bento et al., 2020; Boguta and Sokołowska, 2020, 2016). Component 3 (C3) demonstrated two excitation maxima at $250 \mathrm{~nm}$ and $315 \mathrm{~nm}$, and an emission maximum at $395 \mathrm{~nm}$. C3 resembled microbial humic-like compounds from aquatic environments 
381 (Coble, 1996; Osburn et al., 2011). This component is probably a product of microbial 382 activity and thus of autochthonous origin (Yamashita et al., 2008).
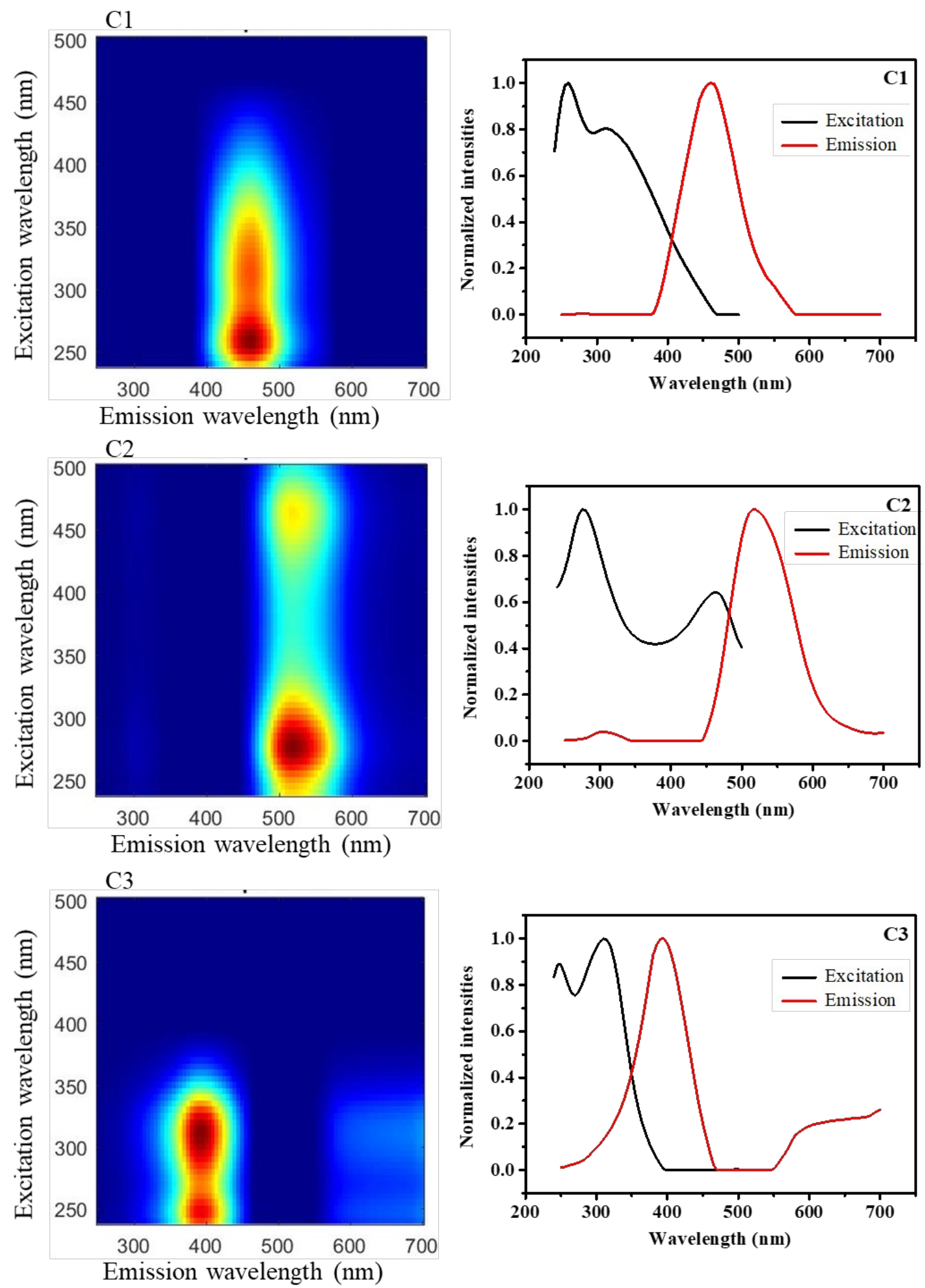
384 Figure 4. Excitation-emission matrix contour plots of the three parallel factor analysis 385 components (left) and their excitation and emission spectra (right). The PARAFAC model was made for a dataset with all samples, thus allowing us 387 to compare the component contributions. Figures 5 and 6 show the fluorescent 388 contributions of each component identified by PARAFAC for EOMSed and 389 WEOMSed, respectively, along with the sediment cores in the different stations, 390 corrected for the analytical dilution factor. For EOMSed (Figure 5), the average 391 fluorescent contribution of C1 was higher in decreasing order for the Piracicaba River > 392 Tietê River $>$ confluence region. This shows that small molecules make a greater 393 contribution to the EOMSed arrangement of the Piracicaba River. The average 394 fluorescent contribution of C2 had the same decreasing order as that of C1 (Piracicaba 395 River $>$ Tietê River $>$ confluence region), showing that complex structures in the form 396 of aromatic and polyaromatic moieties make a greater contribution to the EOMSed 397 arrangement of the Piracicaba River. The average fluorescent contribution of C3 was 398 higher in decreasing order for the Tietê River $>$ Piracicaba River $>$ confluence region, 399 showing that microbial-derived products make a greater contribution to the EOMSed 400 arrangement of the Tietê River. Thus, EOMSed from the Piracicaba River contains 401 more aromatics, while EOMSed from the Tietê River contains more microbial-derived 402 products. These results are in agreement with the SUVA $_{254}$ values and NPOC/TON 403 molar ratios, which showed less aromatic EOMSed with more nitrogenous structures for 404 the Tietê River compared to the Piracicaba River. The low NPOC/TON molar ratio may 405 be the main reason for the higher microbial activity and the consequent presence of 406 microbial derivatives (C3). 
Fluorescent intensity (u. a.)
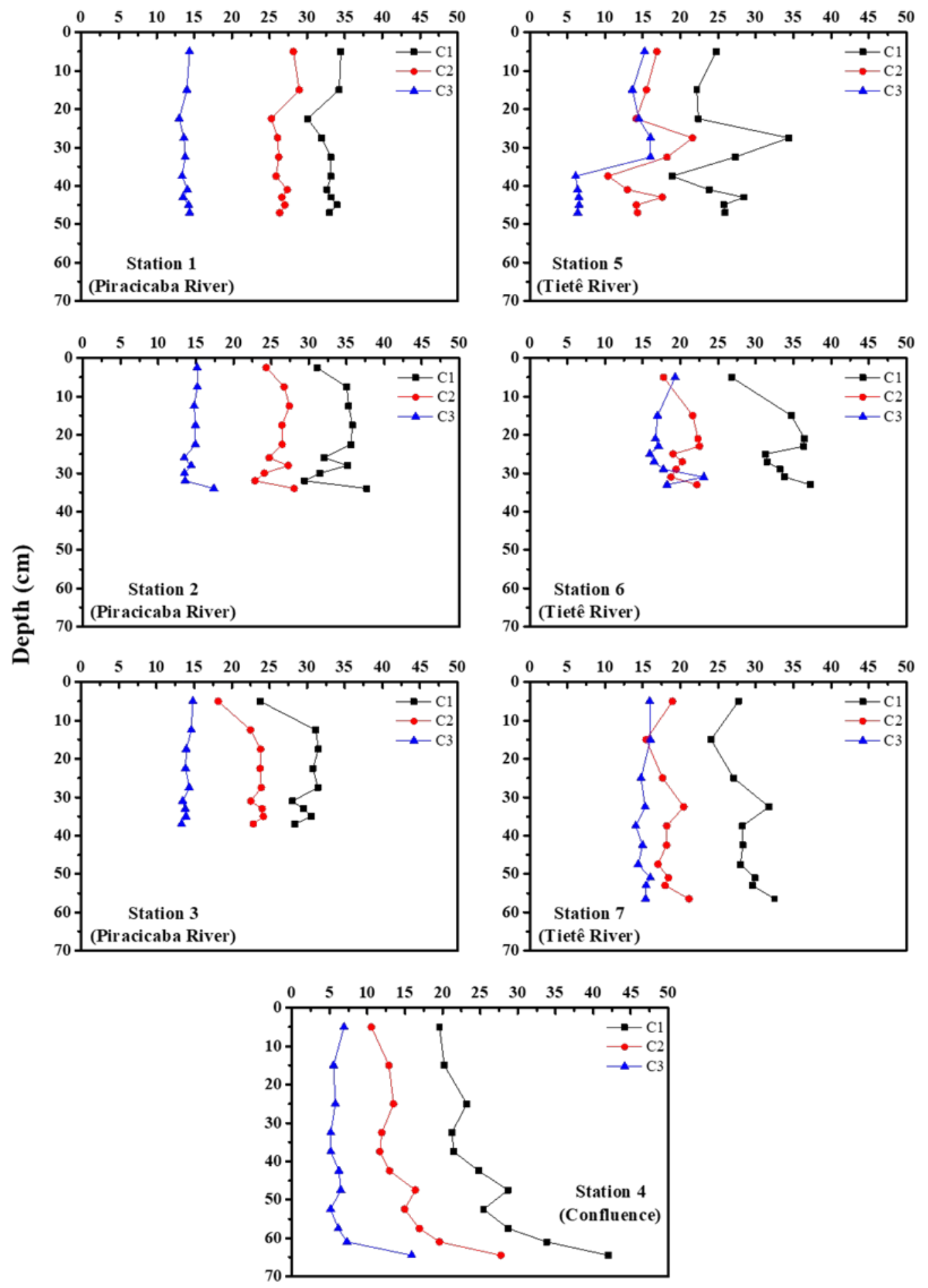

408 Figure 5. Fluorescent intensity of components $(\mathrm{C} 1, \mathrm{C} 2$, and $\mathrm{C} 3)$ taken from the 409 extracted organic matter from sediments along with the sediment core identified by 410 parallel factor analysis. 
In WEOMSed (Figure 6), the average fluorescent contributions of $\mathrm{C} 1, \mathrm{C} 2$, and

412 C3 were higher in decreasing order for the confluence region $>$ Tietê River $>$ Piracicaba

413 River. The extraction of microbial-derived products (C3) was greater for WEOMSed

414 than for EOMSed, and the C3 values were higher at the stations of the Tietê River than

415 the Piracicaba River, indicating its greater microbial activity. The low abundance of C2

416 can be ascribed to the component structure, because humic-like substances with high

417 aromaticity are more soluble in alkaline solution than in water, which may result in the

418 higher relative content of $\mathrm{C} 2$ in alkaline solution; furthermore, the higher $\mathrm{C} 2$

419 concentration in alkaline extracts obfuscates the $\mathrm{C} 3$ concentration. The alkaline medium

420 favored the greater extraction of $\mathrm{C} 1$ and $\mathrm{C} 2$ (humic-like compounds) due to the

421 hydrolysis caused in the functional groups of humic molecules bonded to the surface of

422 the mineral from sediment (Kleber and Lehmann, 2019; Olk et al., 2019).

423 The optical properties of EOMSed proved to be more efficient for assessing the

424 quality and composition of sediments than those of WEOMSed due to the better

425 discrimination between the fluorescence components in the alkaline extracts. Although

426 water extraction has been used to assess OM sources and link contamination in polluted

427 urban rivers (Chen et al., 2019; Zhang et al., 2020), in our study, alkaline extracts were

428 better at describing the properties of OM. 
Fluorescent intensity (u. a.)
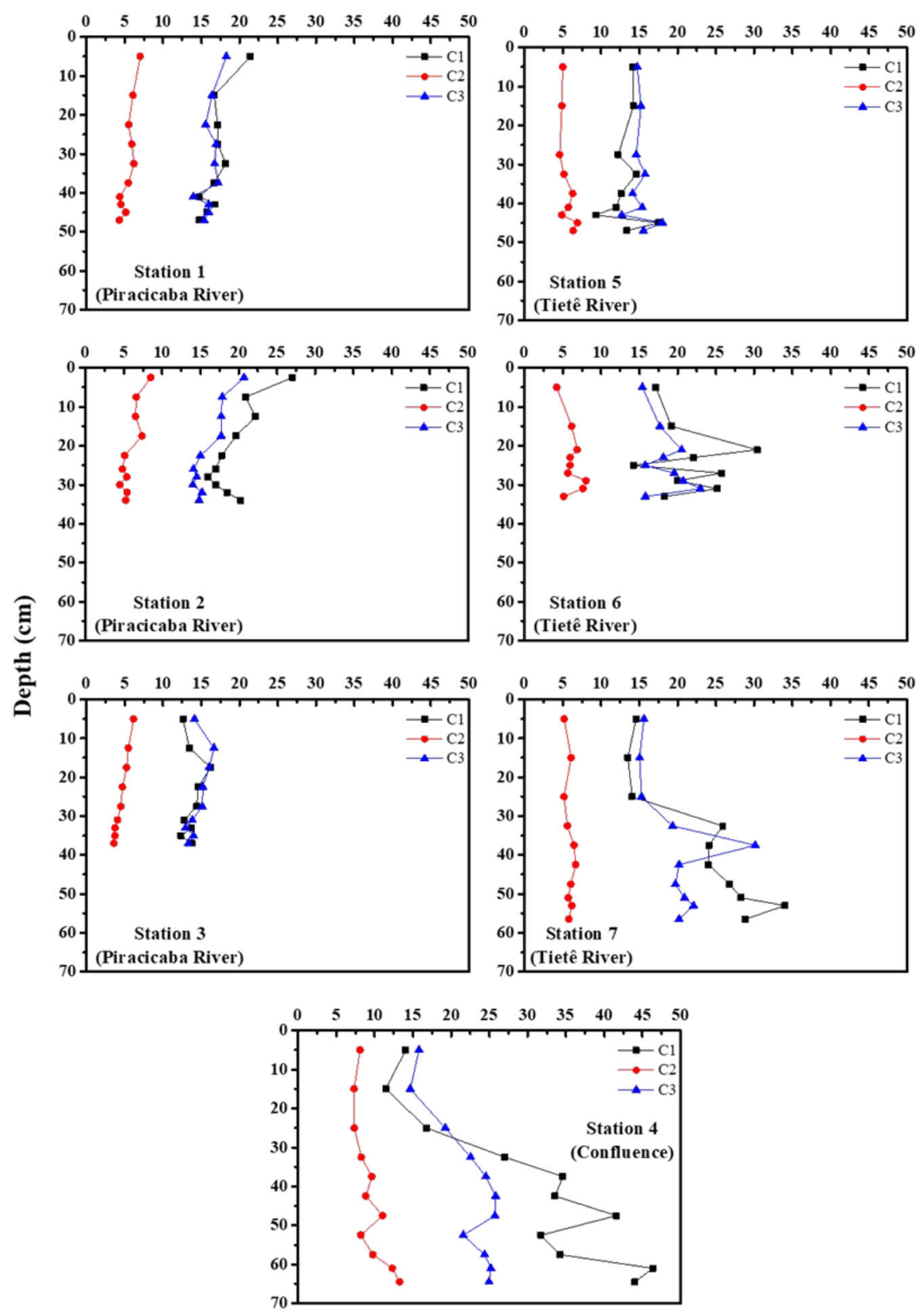

430 Figure 6. Fluorescent intensity of components $(\mathrm{C} 1, \mathrm{C} 2$, and $\mathrm{C} 3)$ taken from water-

431 extracted organic matter from sediments along with sediment core identified by parallel

432 factor analysis. 
433 3.4. Features of extractable organic matter from sediments from the Piracicaba and

434 Tietê Rivers

435 The neutral water solution enabled the better extraction of small molecules

436 (blue-shifted), which are free from the mineral fraction in the sediments. While the

437 alkaline solution favors the extraction of more complex substances (red-shifted). The

438 results obtained with EEM-PARAFAC together with $\mathrm{SUVA}_{254}$ values and NPOC/TON

439 molar ratio allowed for the total assessment of EOMSed quality.

440 The differences between the EOMSed compositions in sediments were

441 highlighted by the SUVA 254 values, NPOC/TON molar ratios, and EEM-PARAFAC.

442 Although the most abundant component in EOMSed from the two rivers is humic-like

443 with the lowest molecular weight (C1), the aromaticity of EOMSed from the Piracicaba

444 River was evidenced by the greater contribution of C2 and $\mathrm{SUVA}_{254}$ values. Conversely,

445 EOMSed from the Tietê River had greater microbial activity due to the greater

446 contribution of $\mathrm{C} 3$, the presence of small molecules (lower $\mathrm{C} 2$ contribution), and the

447 presence of nitrogenous structures. Based on the analyses performed, it was not possible

448 to further identify the compositional alteration of EOMSed and WEOMSed, which may

449 be related to their similar deposition.

450 The origin of EOMSed is inferred from the results obtained here. The

451 NPOC/TON molar ratios calculated for EOMSed from the Piracicaba River indicate

452 that EOMSed can form in the aquatic body (autochthonous). The contributions of two

453 humic-like components in alkaline extracts indicate that EOMSed may also originate

454 from soil OM (allochthon). According to the NPOC/TON molar ratios calculated for

455 EOMSed from the Tietê River as well as the greater microbial activity in this aquatic

456 ecosystem, it can be inferred that the origin of EOMSed is predominantly 
457 allochthonous, mainly due to the discharge of domestic sewage, which is indicated by

458 the higher content of TC present in the Tietê River sediments.

459

\section{4. Conclusion}

461 EOMSed from the Piracicaba and Tietê Rivers was mainly characterized by an 462 arrangement of low molecular weight compounds. However, EOMSed from the 463 Piracicaba River presented more aromatic moieties and fewer nitrogenous structures 464 compared to the Tietê River. The presence of nitrogenous structures and fluorophores 465 related to microbial activity can be an indicator of OM quality, which could be used as a 466 global indicator of the river state. Thus, the combination of elemental and spectroscopic 467 techniques allows for the successful deciphering of extracted OM characteristics. This 468 approach can therefore be used as a tool to assess the quality of aquatic bodies.

469

\section{Declaration of competing interest}

471 The authors declare that they have no known competing financial interests or 472 personal relationships that could have appeared to influence the work reported in this 473 paper.

474

\section{Acknowledgements}

476 This study was partly financed by the Coordenação de Aperfeiçoamento de 477 Pessoal de Nível Superior - Brasil (CAPES) Finance Code 001 grant number 478 (88882.331025/2019-01) for the fellowship provided to Carla Pereira de Morais, 479 FAPESP grant number (2013/07276-1), and IHSS grant number (TRA 2019-9). The 480 authors would like to thank Dr. R. Redon for providing support for PROGMEFF. 


\section{References}

Bento, L.R., Constantino, I.C., Tadini, A.M., Melo, C.A., Ferreira, O.P., Moreira, A.B., Bisinoti, M.C., 2020. Chemical and Spectroscopic Characteristics of Anthrosol (Amazonian Dark Earth) and Surrounding Soil from the Brazilian Amazon Forest: Evaluation of Mineral and Organic Matter Content by Depth. J. Braz. Chem. Soc. 31, 1623-1634. https://doi.org/10.21577/0103-5053.20200048

Bernardo, N., Watanabe, F., Rodrigues, T., Alcântara, E., 2016. Evaluation of the suitability of MODIS, OLCI and OLI for mapping the distribution of total suspended matter in the Barra Bonita Reservoir (Tietê River, Brazil). Remote Sens. Appl. Soc. Environ. 4, 68-82. https://doi.org/10.1016/j.rsase.2016.06.002

Bloesch, J., 2009. Sediments of Aquatic Ecosystems, in: Likens, G.E. (Ed.), Encyclopedia of Inland Waters. Academic Press, Oxford, pp. 479-490. https://doi.org/10.1016/B978-012370626-3.00210-6

Boguta, P., Sokołowska, Z., 2020. Zinc binding to fulvic acids: Assessing the impact of $\mathrm{pH}$, metal concentrations and chemical properties of fulvic acids on the mechanism and stability of formed soluble complexes. Molecules 25, 1297. https://doi.org/10.3390/molecules25061297

Boguta, P., Sokołowska, Z., 2016. Interactions of Zn(II) Ions with Humic Acids Isolated from Various Type of Soils. Effect of pH, Zn Concentrations and Humic Acids Chemical Properties. PLoS One 11, 1-20. https://doi.org/10.1371/journal.pone.0153626

Borisover, M., Laor, Y., Parparov, A., Bukhanovsky, N., Lado, M., 2009. Spatial and seasonal patterns of fluorescent organic matter in Lake Kinneret (Sea of Galilee) and its catchment basin. Water Res. 43, 3104-3116. https://doi.org/10.1016/j.watres.2009.04.039

Brailsford, F.L., Glanville, H.C., Golyshin, P.N., Johnes, P.J., Yates, C.A., Jones, D.L., 2019. Microbial uptake kinetics of dissolved organic carbon (DOC) compound groups from river water and sediments. Sci. Rep. 9, 11229. https://doi.org/10.1038/s41598-019-47749-6

Brym, A., Paerl, H.W., Montgomery, M.T., Handsel, L.T., Ziervogel, K., Osburn, C.L., 2014. Optical and chemical characterization of base-extracted particulate organic 
Burdige, D.J., 2007. Preservation of organic matter in marine sediments: Controls, mechanisms, and an imbalance in sediment organic carbon budgets? Chem. Rev. 107, 467-485. https://doi.org/10.1021/cr050347q

Burone, L., Muniz, P., Pires-vanin, A.N.A.M.S., 2003. Spatial distribution of organic matter in the surface sediments of Ubatuba Bay (Southeastern - Brazil) 75, 77-90. https://doi.org/10.1590/S0001-37652003000100009

Castillo, M.M., 2020. Suspended sediment, nutrients, and chlorophyll in tropical floodplain lakes with different patterns of hydrological connectivity. Limnologica 82, 125767. https://doi.org/10.1016/j.limno.2020.125767

CETESB - Companhia de Tecnologia de Saneamento Ambiental, 2018. Relatório anual de Qualidade das Águas interiores no Estado de São Paulo 2017. < https://cetesb.sp.gov.br/aguas-interiores/wp-content/uploads/sites/12/2018/06/Relat $\%$ C3\%B3rio-de-Qualidade-das-\%C3\%81 guas-Interiores-no-Estado-de-S \%C3\%A3o-Paulo-2017.pdf>.

Chen, Z., Zhu, Z., Song, J., Liao, R., Wang, Y., Luo, X., Nie, D., Lei, Y., Shao, Y., Yang, W., 2019. Linking biological toxicity and the spectral characteristics of contamination in seriously polluted urban rivers. Environ. Sci. Eur. 31, 1-10. https:/doi.org/10.1186/s12302-019-0269-y

Coble, P.G., 1996. Characterization of marine and terrestrial DOM in seawater using excitation-emission matrix spectroscopy. Mar. Chem. 51, 325-346. https://doi.org/10.1016/0304-4203(95)00062-3

Cole, J.J., Prairie, Y.T., Caraco, N.F., McDowell, W.H., Tranvik, L.J., Striegl, R.G., Duarte, C.M., Kortelainen, P., Downing, J.A., Middelburg, J.J., Melack, J., 2007. Plumbing the global carbon cycle: Integrating inland waters into the terrestrial carbon budget. Ecosystems 10, 171-184. https://doi.org/10.1007/s10021-0069013-8

Cruz, B.B., Manfré, L.A., Ricci, D.S., Brunoro, D., Appolinario, L., Quintanilha, J.A., 2017. Environmental fragility framework for water supply systems: a case study in the Paulista Macro Metropolis area (SE Brazil). Environ. Earth Sci. 76, 441. 
545

546

dos Santos, M.A., Rosa, L.P., Sikar, B., Sikar, E., dos Santos, E.O., 2006. Gross greenhouse gas fluxes from hydro-power reservoir compared to thermo-power plants. Energy Policy 34, 481-488. https://doi.org/10.1016/j.enpol.2004.06.015

Du, Y.X., Lu, Y.H., Roebuck, J.A., Liu, D., Chen, F.Z., Zeng, Q.F., Xiao, K., He, H., Liu, Z.W., Zhang, Y.L., Jaffé, R., 2021. Direct versus indirect effects of human activities on dissolved organic matter in highly impacted lakes. Sci. Total Environ. 752, 141839. https://doi.org/10.1016/j.scitotenv.2020.141839

Duarte, C.M., 1995. Submerged aquatic vegetation in relation to different nutrient regimes. Ophelia 41, 87-112. https://doi.org/10.1080/00785236.1995.10422039

Dungait, J.A.J., Hopkins, D.W., Gregory, A.S., Whitmore, A.P., 2012. Soil organic matter turnover is governed by accessibility not recalcitrance. Glob. Chang. Biol. 18, 1781-1796. https://doi.org/10.1111/j.1365-2486.2012.02665.x

Edzwald, J.K., Tobiason, J.E., 2011. Water quality \& treatment. A handbook on drinking water, 6th ed. McGraw-Hill Professional Publishing, Colorado.

Engel, M.H., Macko, S.A., 2013. Organic Geochemistry: Principles and Applications. Springer science \& business media.

Funkey, C.P., Conley, D.J., Stedmon, C.A., 2019. Sediment alkaline-extracted organic matter (AEOM)fluorescence: An archive of Holocene marine organic matter origins. Sci. Total Environ. 676, 298-304. https://doi.org/10.1016/j.scitotenv.2019.04.170

Guigue, J., Mathieu, O., Lévêque, J., Mounier, S., Laffont, R., Maron, P.A., Navarro, N., Chateau, C., Amiotte-Suchet, P., Lucas, Y., 2014. A comparison of extraction procedures for water-extractable organic matter in soils. Eur. J. Soil Sci. 65, 520530. https://doi.org/10.1111/ejss.12156

He, Z., Xu, S., Zhao, Y., Pan, X., 2019. Methane emissions from aqueous sediments are influenced by complex interactions among microbes and environmental factors: A modeling study. Water Res. 166, 115086. https://doi.org/10.1016/j.watres.2019.115086

Henrichs, S.M., 1992. Early diagenesis of organic matter in marine sediments: progress 


\section{3(92)90098-U}

Kaushal, S., Binford, M.W., 1999. Relationship between C:N ratios of lake sediments, organic matter sources, and historical deforestation in Lake Pleasant, Massachusetts, USA. J. Paleolimnol. 22, 439-442. https://doi.org/10.1023/A:1008027028029

Kindler, R., Siemens, J., Kaiser, K., Walmsley, D.C., Bernhofer, C., Buchmann, N., Cellier, P., Eugster, W., Gleixner, G., Grunwald, T., Heim, A., Ibrom, A., Jones, S.K., Jones, M., Klumpp, K., Kutsch, W., Larsen, K.S., Lehuger, S., Loubet, B., Mckenzie, R., Moors, E., Osborne, B., Pilegaard, K., Rebmann, C., Saunders, M., Schmidt, M.W.I., Schrumpf, M., Seyfferth, J., Skiba, U., Soussana, J.F., Sutton, M.A., Tefs, C., Vowinckel, B., Zeeman, M.J., Kaupenjohann, M., 2011. Dissolved carbon leaching from soil is a crucial component of the net ecosystem carbon balance. Glob. Chang. Biol. 17, 1167-1185. https://doi.org/10.1111/j.13652486.2010.02282.x

Kleber, M., Lehmann, J., 2019. Humic Substances Extracted by Alkali Are Invalid Proxies for the Dynamics and Functions of Organic Matter in Terrestrial and Aquatic Ecosystems. J. Environ. Qual. 48, 207-216. https://doi.org/10.2134/jeq2019.01.0036

Kothawala, D.N., Murphy, K.R., Stedmon, C.A., Weyhenmeyer, G.A., Tranvik, L.J., 2013. Inner filter correction of dissolved organic matter fluorescence. Limnol. Oceanogr. Methods 11, 616-630. https://doi.org/10.4319/lom.2013.11.616

Kowalczuk, P., Durako, M.J., Young, H., Kahn, A.E., Cooper, W.J., Gonsior, M., 2009. Characterization of dissolved organic matter fluorescence in the South Atlantic Bight with use of PARAFAC model: Interannual variability. Mar. Chem. 113, 182-196. https://doi.org/10.1016/j.marchem.2009.01.015

Kubo, A., Kanda, J., 2020. Coastal urbanization alters carbon cycling in Tokyo Bay. Sci. Rep. 10, 1-11. https://doi.org/10.1038/s41598-020-77385-4

Kumwimba, M.N., Zhu, B., Suanon, F., Muyembe, D.K., Dzakpasu, M., 2017. Longterm impact of primary domestic sewage on metal/loid accumulation in drainage ditch sediments, plants and water: Implications for phytoremediation and 
restoration. Sci. Total Environ. 581-582, 773-781.

https://doi.org/10.1016/j.scitotenv.2017.01.007

Kurek, M.R., Harir, M., Shukle, J.T., Schroth, A.W., Schmitt-Kopplin, P., Druschel, G.K., 2020. Chemical fractionation of organic matter and organic phosphorus extractions from freshwater lake sediment. Anal. Chim. Acta 1130, 29-38. https://doi.org/10.1016/j.aca.2020.07.013

Lawaetz, A.J., Stedmon, C.A., 2009. Fluorescence intensity calibration using the Raman scatter peak of water. Appl. Spectrosc. 63, 936-940. https://doi.org/10.1366/000370209788964548

Lehmann, J., Hansel, C.M., Kaiser, C., Kleber, M., Maher, K., Manzoni, S., Nunan, N., Reichstein, M., Schimel, J.P., Torn, M.S., Wieder, W.R., Kögel-Knabner, I., 2020. Persistence of soil organic carbon caused by functional complexity. Nat. Geosci. 13, 529-534. https://doi.org/10.1038/s41561-020-0612-3

Meyers, P.A., 1994. Preservation of elemental and isotopic source identification of sedimentary organic matter. Chem. Geol. 114, 289-302. https://doi.org/10.1016/0009-2541(94)90059-0

Morais, C.P., Nicolodelli, G., Mitsuyuki, M.C., Silva, K.S.G., Mauad, F.F., Mounier, S., Milori, D.M.B.P., 2021. Total phosphorus determination in eutrophic tropical river sediments by laser-induced breakdown spectroscopy techniques. Anal. Methods 13, 77-83. https://doi.org/10.1039/d0ay02008g

Mounier, S., Zhao, H., Garnier, C., Redon, R., 2011. Copper complexing properties of dissolved organic matter: PARAFAC treatment of fluorescence quenching. Biogeochemistry 106, 107-116. https://doi.org/10.1007/s10533-010-9486-6

Muller, M., Jimenez, J., Antonini, M., Dudal, Y., Latrille, E., Vedrenne, F., Steyer, J.P., Patureau, D., 2014. Combining chemical sequential extractions with 3D fluorescence spectroscopy to characterize sludge organic matter. Waste Manag. 34, 2572-2580. https://doi.org/10.1016/j.wasman.2014.07.028

Murdoch, A., MacKnight, S. (Eds.), 1991. Handbook of Techniques for Aquatic Sediments Sampling. CRC Press, Boca Raton.

Murphy, K.R., Stedmon, C.A., Wenig, P., Bro, R., 2014. OpenFluor- An online spectral 

library of auto-fluorescence by organic compounds in the environment. Anal. Methods 6, 658-661. https://doi.org/10.1039/c3ay41935e

Nixon, S.W., 1995. Coastal marine eutrophication: A definition, social causes, and future concerns. Ophelia 41, 199-219. https://doi.org/10.1080/00785236.1995.10422044

Olk, D.C., Bloom, P.R., Perdue, E.M., McKnight, D.M., Chen, Y., Farenhorst, A., Senesi, N., Chin, Y.-P., Schmitt-Kopplin, P., Hertkorn, N., Harir, M., 2019. Environmental and Agricultural Relevance of Humic Fractions Extracted by Alkali from Soils and Natural Waters. J. Environ. Qual. 48, 217-232. https://doi.org/10.2134/jeq2019.02.0041

Osburn, C.L., Boyd, T.J., Montgomery, M.T., Bianchi, T.S., Coffin, R.B., Paerl, H.W., 2016. Optical proxies for terrestrial dissolved organic matter in estuaries and coastal waters. Front. Mar. Sci. 2, 127. https://doi.org/10.3389/fmars.2015.00127

Osburn, C.L., Wigdahl, C.R., Fritz, S.C., Saros, J.E., 2011. Dissolved organic matter composition and photoreactivity in prairie lakes of the U.S. Great Plains. Limnol. Oceanogr. 56, 2371-2390. https://doi.org/10.4319/lo.2011.56.6.2371

Redon, R., Mounier, S., 2018. PROGMEEF. < https://woms18.univ-tln.fr/progmeef/>.

Rocha, P.S., Azab, E., Schmidt, B., Storch, V., Hollert, H., Braunbeck, T., 2010. Changes in toxicity and dioxin-like activity of sediments from the Tietĉ River (São Paulo, Brazil). Ecotoxicol. Environ. Saf. 73, 550-558. https://doi.org/10.1016/j.ecoenv.2009.12.017

Rocha, P.S., Bernecker, C., Strecker, R., Mariani, C.F., Pompĉo, M.L.M., Storch, V., Hollert, H., Braunbeck, T., 2011. Sediment-contact fish embryo toxicity assay with Danio rerio to assess particle-bound pollutants in the Tietĉ River Basin (São Paulo, Brazil). Ecotoxicol. Environ. Saf. 74, 1951-1959. https://doi.org/10.1016/j.ecoenv.2011.07.009

Rodrigues, T., Alcântara, E., Rotta, L., Bernardo, N., Watanabe, F., 2020. An investigation into the relationship between light absorption budget and trophic status in inland waters. Ecol. Indic. 115, 106410. https://doi.org/10.1016/j.ecolind.2020.106410 
665 Schorer, M., Eisele, M., 1997. Accumulation of inorganic and organic pollutants by 666 biofilms in the aquatic environment. Water, Air Soil Pollut. 99, 651-659.

667 Shutova, Y., Baker, A., Bridgeman, J., Henderson, R.K., 2014. Spectroscopic 668 characterisation of dissolved organic matter changes in drinking water treatment: 669 From PARAFAC analysis to online monitoring wavelengths. Water Res. 54, 159670 169. https://doi.org/10.1016/j.watres.2014.01.053

671 Sire, J., Klavins, M., Kreismanis, J., Jansone, S., 2009. Impact of the process of isolating humic acids from peat on their properties. Can. J. Civ. Eng. 36, 345-355. https://doi.org/10.1139/S08-052

Smith, W.S., Espíndola, E.L.G., Rocha, O., 2014. Environmental gradient in reservoirs of the medium and low Tietê River: limnological differences through the habitat sequence. Acta Limnol. Bras. 26, 73-88. https://doi.org/10.1590/s2179$975 \times 2014000100009$

Soares da Silva, L., Constantino, I.C., Bento, L.R., Tadini, A.M., Bisinoti, M.C., Boscolo, M., Ferreira, O.P., Mounier, S., Piccolo, A., Spaccini, R., Cornélio, M.L., Moreira, A.B., 2020. Humic extracts from hydrochar and Amazonian Anthrosol: Molecular features and metal binding properties using EEM-PARAFAC and 2D FTIR correlation analyses. Chemosphere 256, 1-12. https://doi.org/10.1016/j.chemosphere.2020.127110

Veres, D.S., 2002. A comparative study between loss on ignition and total carbon analysis on mineralogenic sediments. Stud. UBB Geol. 47, 171-182. http://dx.doi.org/10.5038/1937-8602.47.1.13

Walker, S.A., Amon, R.M.W., Stedmon, C.A., 2013. Variations in high-latitude riverine fluorescent dissolved organic matter: A comparison of large Arctic rivers. J. Geophys. Res. Biogeosciences 118, 1689-1702.

691 Weishaar, J.L., Fram, M.S., Fujii, R., Mopper, K., 2003. Evaluation of Specific 692 Ultraviolet Absorbance as an Indicator of the Chemical Composition and 695 Yamashita, Y., Cory, R.M., Nishioka, J., Kuma, K., Tanoue, E., Jaffé, R., 2010a. 

Fluorescence characteristics of dissolved organic matter in the deep waters of the Okhotsk Sea and the northwestern North Pacific Ocean. Deep. Res. Part II Top. Stud. Oceanogr. 57, 1478-1485. https://doi.org/10.1016/j.dsr2.2010.02.016

Yamashita, Y., Jaffé, R., Maie, N., Tanoue, E., 2008. Assessing the dynamics of dissolved organic matter (DOM) in coastal environments by excitation emission matrix fluorescence and parallel factor analysis (EEM-PARAFAC). Limnol. Oceanogr. 53, 1900-1908. https://doi.org/10.4319/lo.2008.53.5.1900

Yamashita, Y., Scinto, L.J., Maie, N., Jaffé, R., 2010b. Dissolved Organic Matter Characteristics Across a Subtropical Wetland's Landscape: Application of Optical Properties in the Assessment of Environmental Dynamics. Ecosystems 13, 10061019. https://doi.org/10.1007/s10021-010-9370-1

Zepp, R.G., Sheldon, W.M., Moran, M.A., 2004. Dissolved organic fluorophores in southeastern US coastal waters: Correction method for eliminating Rayleigh and Raman scattering peaks in excitation-emission matrices. Mar. Chem. 89, 15-36. https://doi.org/10.1016/j.marchem.2004.02.006

Zhang, L., Liu, H., Peng, Y., Zhang, Y., Sun, Q., 2020. Characteristics and significance of dissolved organic matter in river sediments of extremely water-deficient basins: A Beiyun River case study. J. Clean. Prod. 277, 123063. https://doi.org/10.1016/j.jclepro.2020.123063 